\title{
Vertical Integration and Competition
}

\section{Citation}

Aghion, Philippe, Rachel Griffith, and Peter Howitt. 2006. "Vertical Integration and Competition." American Economic Review 96 (2) (May): 97-102. doi:10.1257/000282806777211595.

\section{Published Version}

doi:10.1257/000282806777211595

\section{Permanent link}

http://nrs.harvard.edu/urn-3:HUL.InstRepos:34330170

\section{Terms of Use}

This article was downloaded from Harvard University's DASH repository, and is made available under the terms and conditions applicable to Other Posted Material, as set forth at http:// nrs.harvard.edu/urn-3:HUL.InstRepos:dash.current.terms-of-use\#LAA

\section{Share Your Story}

The Harvard community has made this article openly available.

Please share how this access benefits you. Submit a story.

\section{Accessibility}




\title{
THE ROOTS OF INNOVATION ${ }^{\dagger}$
}

\section{Vertical Integration and Competition}

\author{
By Philippe Aghion, Rachel Griffith, And Peter Howitw*
}

This paper is part of a research program analyzing how competition affects aggregate innovative activity through its effects on firms' organization. In previous work (Aghion et al., 2005a), we found an inverted-U shaped relationship between competition and innovation. Our explanation emphasized the "composition effect" of competition on the steady-state distribution of technological gaps across industries. Our focus here is on firms' decisions whether or not to integrate vertically with their suppliers. We provide evidence of a U-shaped relationship between competition and vertical integration. Our explanation is based on the following idea: a moderate increase in product market competition will reduce a producer's incentive to integrate by improving the outside options of her nonintegrated suppliers and hence raising their incentive to innovate. Too much competition will raise the producer's incentive to integrate, however, by allowing nonintegrated suppliers to capture most of the innovation surplus.

Finding a U-shaped relationship between competition and vertical integration sheds light on the debate over the "Transaction Cost Economics" (TCE) approach to vertical integration pioneered by Oliver Williamson $(1975,1985)$ versus the "Property Right Theory" (PRT) approach developed by Sanford Grossman and

$\dagger$ Discussants: Sam Kortum, University of Minnesota; Mark Duggan, University of Maryland; Joel Waldfogel, University of Pennsylvania; Shane Greenstein, Northwestern University.

* Aghion: Department of Economics, Harvard University, Littauer 231, Cambridge, MA 02138 (e-mail: p-aghion@ harvard.edu); Griffith: IFS, 7 Ridgmont Street, London WC1E 7AC, U.K. (e-mail: rachel-g@ifs.org.uk); Howitt: Department of Economics, Brown University, Providence, RI 02912 (e-mail: Peter_Howitt@brown.edu). This is the short version of an essay in honor of Jean-Michel Grandmont. We thank Pol Antràs, Oliver Hart, and especially Sam Kortum for useful comments.
Oliver Hart (1986) and by Hart and John Moore (1990). ${ }^{1}$ According to the TCE approach, vertical integration is a way for contracting parties involved in a specific relationship to limit ex post bargaining inefficiencies due to holdup and thereby minimize the loss in ex ante investment that would result from it. This approach thus predicts a positive correlation between vertical integration and the degree of relation specificity. According to the PRT approach, the ownership structure will affect not so much the ex post bargaining efficiency as the relative bargaining powers of the (two) contracting parties, and therefore their relative ex ante investment incentives. Thus, while vertical integration should enhance both parties' investments positively in the TCE approach by reducing the extent of ex post inefficiency, in the PRT approach ownership by one party, say the buyer, will enhance the buyer's ex ante incentives at the expense of the seller's, as it enhances the buyer's bargaining power ex post at the expense of the seller's. ${ }^{2}$ Thus, the TCE approach predicts that increased competition on the producer's (or supplier's) market, which reduces the overall degree of asset specificity, should therefore reduce the need for vertical integration in order to preserve ex ante investment incentives by either party. On the other hand, as we show below, the PRT approach allows the U-shaped relationship between vertical integration and competition that we find empirically.

\footnotetext{
${ }^{1}$ Michael Whinston (2001) first derived testable implications of the two approaches.

${ }^{2}$ Daron Acemoglu et al. (2004) use cross-industry panel data to discriminate between the two theories. Using technology intensity to measure relationship-specific investments, they look at the relationship between pairs of supplying and producing industries and show that, as predicted by the PRT approach, (backward) vertical integration is significantly correlated with the investment incentives of suppliers and producers, as measured by their respective $\mathrm{R} \& \mathrm{D}$ intensities, but with opposite signs.
} 


\section{Basic Framework}

Consider an economy composed of individuals with risk-neutral preferences for consumption. A general good is produced under perfect competition with a continuum of intermediate inputs, according to

$$
y=\int_{0}^{1} x_{i}^{\alpha} d i, \quad 0<\alpha<1 .
$$

We focus on a representative intermediate sector, dropping the $i$ subscript from here on. In each sector, a monopolist produces her intermediate product according to

$$
x=f(q, s)
$$

where $q$ is the input of a general good used as capital and $s$ is the input of a specialized good used only in this sector, and available in supply equal to one. The production function for the intermediate product is

$$
f(q, s)= \begin{cases}q & \text { if } s \geq 1 \\ 0 & \text { otherwise. }\end{cases}
$$

Thus, the specialized input $s$ is indispensable to production.

Although she enjoys monopoly power, the intermediate good producer may face a competitive fringe of potential imitators that can produce the same intermediate product but at higher unit cost. An imitator's production function is

$$
f^{m}(q, s)= \begin{cases}a q & \text { if } s \geq 1 \\ 0 & \text { otherwise }\end{cases}
$$

where $a<1$ is a direct measure of the degree of product market competition in the intermediate input market.

If the incumbent firm (the "entrepreneur") in this sector manages to obtain the services of the specialized input producer (the "manager") in that sector, she faces no effective competition, since potential imitators then do not have access to the specialized input. The incumbent firm can then sell to the general sector at the unconstrained monopoly price, which is equal to the marginal product of the intermediate good in producing the general good:

$$
p=\alpha x^{\alpha-1} .
$$

Thus, the intermediate producer will choose $x$ to maximize joint surplus, namely

$$
\pi=\max _{x}\left\{\alpha x^{\alpha}-x\right\}
$$

which yields

$$
\pi=(1-\alpha) \alpha^{(1+\alpha) /(1-\alpha)} .
$$

Before determining how this surplus is divided between the entrepreneur and the manager, we need to compute what the manager would obtain if he sold his specialized input to an imitator. Since the fringe of imitators is competitive, the manager should get the whole surplus, $\pi^{m}$, from selling to an imitator. That surplus, in turn, is determined by the same maximization program as above, except that the production function $f$ is replaced by $f^{m}$, namely

$$
\pi^{m}=\max _{x}\left\{\alpha x^{\alpha}-x / a\right\}
$$

which yields

$$
\pi^{m}=\chi \pi
$$

where

$$
\chi=a^{\alpha /(1-\alpha)}
$$

is also a measure of product market competition.

At the beginning of each period the entre- 
preneur in any sector decides whether or not to integrate with her manager. Then she invests in quality-enhancing innovation. If she successfully innovates, then she turns to the manager in that sector for him to come up with a component for the new technology. Then a competitive fringe of potential imitators shows up with probability $\eta>0$. After the fringe shows up (or not), if the component has been successfully produced then the entrepreneur and the manager bargain over the surplus. Otherwise they both get zero profits, as the previous technology keeps prevailing in that sector.

We now analyze the outcome of ex post bargaining between the entrepreneur and the manager in each sector. First, if a competitive fringe of imitators has shown up, the entrepreneur must concede $\pi^{m}$ to the manager to secure his specialized input. If no competitive fringe shows up, or if the entrepreneur integrates backward with her manager, then ex post bargaining results in the entrepreneur and the manager splitting the total surplus $50-50$, so that each gets $\pi / 2$.

The entrepreneur in any sector must invest in $\mathrm{R} \& \mathrm{D}$ in order to innovate. Innovation, in turn, creates the profit opportunity $\pi$. The R\&D cost of innovating with probability $z$ is

$$
d(z)=z^{u_{1}} / u_{1}, \quad u_{1}>1 .
$$

Once a new technology has been invented by the entrepreneur, the manager must create a suitable input or component for that new technology, and her cost of generating such a component with probability $e$ is

$$
c(e)=e^{u_{2}} / u_{2}, \quad u_{2}>1 .
$$

\section{Competition and the Integration Choice}

Suppose that the entrepreneur has chosen to integrate backward with her manager, yielding $\pi / 2$ to each party if both innovate. Once a new technology has been successfully invented, the manager will choose the probability $e$ of discovering the complementary component so as to maximize his expected profit

$$
e \pi / 2-c(e)
$$

which yields

$$
e^{V}=(\pi / 2)^{\varepsilon_{2}}
$$

where $\varepsilon_{2}=\left(u_{2}-1\right)^{-1}$ measures the marginal efficiency of the manager's effort. This choice is unconstrained by any contractual obligation because it cannot be verified.

Moving back one step further, anticipating innovation effort $e^{V}$ by the manager, the entrepreneur will choose her own R\&D intensity $z$ to earn the maximal payoff

$$
U^{V}=\max _{z}\left\{z e^{V} \pi / 2-d(z)\right\} .
$$

Next, suppose that the entrepreneur has chosen not to integrate. Then, once a new technology has been successfully invented the manager will choose the probability $e$ so as to maximize

$$
e \pi(\eta \chi+(1-\eta) / 2)-c(e)
$$

which yields

$$
e^{N}=(\eta \chi+(1-\eta) / 2)^{\varepsilon_{2}} \pi^{\varepsilon_{2}},
$$

which is greater than $e^{V}$ if the competitive fringe is binding $(\chi>1 / 2)$, which we now assume. Moving back again one step, anticipating innovation effort $e^{N}$ by the manager, the entrepreneur will choose her own R\&D intensity $z$ to earn the maximal payoff

$$
\begin{aligned}
U^{N}= & \max _{z}\left\{z e^{N}(\eta(1-\chi)\right. \\
& +(1-\eta) / 2) \pi-d(z)\} .
\end{aligned}
$$

Now consider what happens as the degree of competition $\chi$ varies. Comparison of (1) with (2) yields

LEMMA 1: As the degree of competition $\chi$ increases from $1 / 2$ to 1 , the difference $U^{V}-U^{N}$ 
TABLE 1 -Vertical INTEgRATION AND ENTRy RATES

\begin{tabular}{lcccc}
\hline \hline & $(1)$ & $(2)$ & $(3)$ & $(4)$ \\
& Total entry & Total entry & Total entry & Foreign entry \\
\hline Producing entry rate & -0.618 & -0.149 & -0.666 & -0.606 \\
& $(0.104)$ & $(0.070)$ & $(0.101)$ & $(0.250)$ \\
Producing entry rate ${ }^{2}$ & 0.989 & 0.347 & 1.023 & 11.507 \\
& $(0.223)$ & $(0.177)$ & $(0.210)$ & $(3.937)$ \\
Supplying entry rate & & 0.581 & 0.230 & 1.524 \\
& & $(0.084)$ & $(0.029)$ & $(0.352)$ \\
Supplying entry rate ${ }^{2}$ & & -1.462 & $(0.106$ & -50.712 \\
& & $(0.199)$ & $0.033)$ & $(7.350)$ \\
Age & & 0.006 & $(0.003)$ & 0.008 \\
& & $(0.004)$ & 0.01 & $(0.003)$ \\
Employment & 0.012 & $(0.008)$ & 0.012 \\
& & $(0.008)$ & 0.036 & $(0.008)$ \\
Foreign-owned & 0.081 & $(0.036)$ & 0.090 \\
Share of inputs imported & $(0.041)$ & -0.040 & $(0.042)$ \\
& & & $(0.016)$ & \\
\hline
\end{tabular}

Notes: 15,990 observations at the industry-pair year level, 1980-1992. Dependent variable is proportion of firms in industry pair that are vertically integrated. Numbers in parentheses are robust standard errors, clustered at level of 181 producing industries. Year effects included in all regressions.

either always decreases, always increases, or follows a U-shape (first decreasing and then increasing). The $U$-shape will be observed if and only if the marginal efficiency, $\varepsilon_{2}$, of the manager's effort is large enough and the probability of imitation, $\eta$, is large enough relative to $\varepsilon_{2}$.

\section{PROOF:}

Consider the function

$$
\begin{aligned}
\nu(\chi)= & -(\eta \chi+(1-\eta) / 2)^{\varepsilon_{2}}(\eta(1-\chi) \\
& +(1-\eta) / 2)
\end{aligned}
$$

Once we fully spell out the expressions for (1) and (2), we see that $U^{V}-U^{N}$, regarded as a function of $\chi$, is a positive monotone transformation of the function $\nu$, which in turn is either increasing, or decreasing, or U-shaped in $\eta$; the third case occurs if and only if $\varepsilon_{2}>1$ and $\chi>$ $\left(\varepsilon_{2}-1\right) /\left(\varepsilon_{2}+1\right)$.

Suppose that there is an administrative cost, $c^{V}$, of organizing a vertically integrated firm and a cost, $c^{N}$, of organizing a nonintegrated firm. The net cost of integration, $c^{V}-c^{N}$, is distributed randomly across sectors. So the incidence of vertical integration, $v$, will be the fraction of sectors in which the realization of this net cost is less than the net benefit $U^{V}-U^{N}$. Thus, it follows directly from Lemma 1 that:

PROPOSITION 1: The incidence of vertical integration $v$ cannot be inverted $U$-shaped with respect to the degree of product market competition $\chi$; it is either increasing, or decreasing, or $U$-shaped. It will be U-shaped when the marginal efficiency, $\varepsilon_{2}$, of the manager's effort is large enough and the probability of imitation $\eta$ is large enough relative to $\varepsilon_{2}$.

\section{Empirical Evidence}

We are interested in investigating whether the propensity for firms to integrate vertically varies systematically with the extent of competition in the product market. We use a measure of vertical integration developed in Acemoglu et al. (2004), and we use variation in entry rates across industries to proxy competition.

We use a large nationally representative data set on all U.K. manufacturing plants ${ }^{3}$ over a 13-year

\footnotetext{
${ }^{3}$ This is the U.K. Annual Business Inquiry (ABI), also known as the ARD data. See Acemoglu et al. (2005) for further details. The ARD contains information on all pro-
} 
period (1980-1992) combined with information from the U.K. Input-Output Tables. We identify whether each firm in a producing industry is vertically integrated or not with any firm in each potential supplying industry. Plants are identified by their 4-digit industry. The Input-Output Table indicate the linkages between industries. The Input-Output Table contains information on 77 manufacturing industries (supplying and producing). ${ }^{4}$

We denote a firm as vertically integrated in an industry pair if: (a) there is a trade flow representing at least 1 percent of costs between firms in that producing and supplying industry (indicated in the IO Table); and (b) the firm owns at least one plant operating in each industry. We use these data at the level of the producing-supplying industry pair for each year by aggregating to the industry pair level, defining a variable that is the proportion of producing firms in each industry pair that also own a plant in the supplying industry. The mean of this variable is just under 15 percent. We proxy competition using the entry rate (the number of new firms over the total number of firms) and the entry rate of foreign firms.

The first column of the table shows the correlation between the entry rate (as a proxy for competition) and the proportion of producing firms that are vertically integrated with a supplier. The probability of vertical integration is initially declining in competition but then, at higher levels of competition, is increasing. In column 2 , we include the entry rate in the supplying industry along with the average age and size (measured by employment) of firms in the producing industry, and the proportion of firms in the producing industry that are foreign-owned. Figure 1 shows the pattern of this correlation, normalized to zero at zero entry. At lower levels of entry, as entry increases, the probability of

duction activity located in the United Kingdom. Location, ownership structure, industry, and employment are reported on all plants. Single-plant firms are identified as those reporting units that represent only one plant and that have no sibling, parent, or child plants. Single plants with fewer than 20 employees are dropped from the analysis.

${ }^{4}$ We use the Input-Output Table for 1995, available at www.statistics.gov.uk.

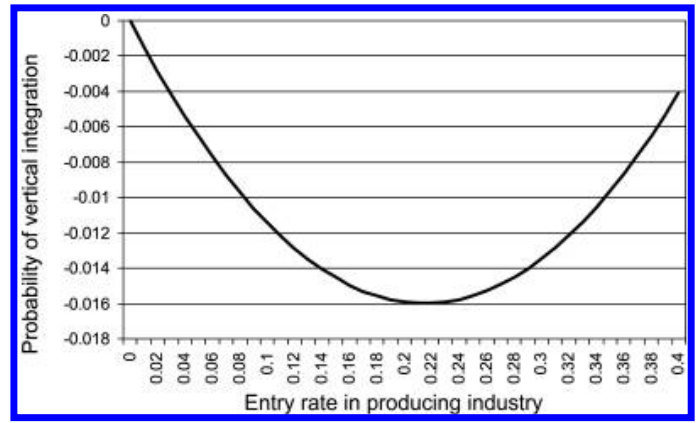

Figure 1. Correlation between Entry and Vertical INTEGRATION

(Calculated using estimates from column (2) of table 1)

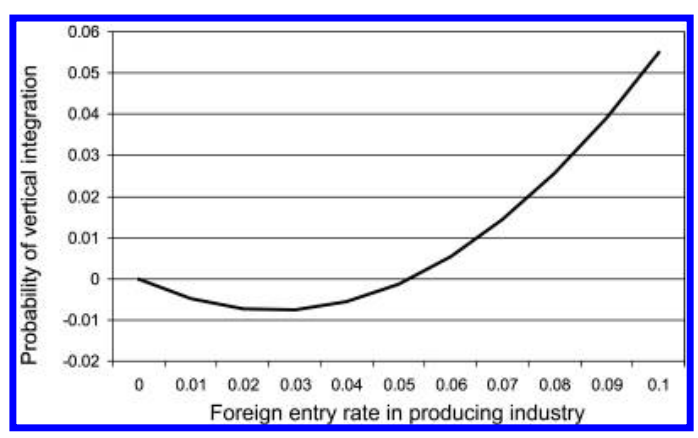

Figure 2. Correlation BetweEn Foreign Entry and VERTICAL INTEGRATION

(Calculated using estimates from column (4) of Table 1)

vertical integration declines (in line with both PRT and TCE approaches). This gradually diminishes and, above a certain level, the correlation switches. As a robustness check in column 3 we also include the share of inputs (used by producers) that are imported.

In column 4 we use an alternative entry rate, looking just at entry by foreign firms. We might be concerned that entry is a noisy measure of competition. Foreign firms are in general larger and represent a more substantial competitive threat. ${ }^{5}$ Figure 2 plots the relationship between entry and vertical integration implied by these estimates. Here we see the upward part of the curve dominates-in line with the predictions of the PRT approach but not the TCE approach.

\footnotetext{
${ }^{5}$ See Aghion et al. (2005b).
} 


\section{Concluding Comments}

In this paper, we have provided some preliminary evidence to suggest that there is a nonlinear relationship between competition and the propensity of firms to integrate vertically. These results seem to be more consistent with the PRT approach of vertical integration than with the TCE approach and they also suggest that organizational considerations may partly explain the observed inverted-U relationship between competition and innovation.

\section{REFERENCES}

Acemoglu, Daron; Aghion, Philippe; Griffith, Rachel and Zillibotti, Fabrizio. "Vertical Integration and Technology: Theory and Evidence." Institute for Fiscal Studies, IFS Working Papers: No. W04/34, 2004.

-Aghion, Philippe; Bloom, Nick; Blundell, Richard W.; Griffith, Rachel and Howitt, Peter. "Competition and Innovation: An Inverted-U Relationship." Quarterly Journal of Economics, 2005a, 120(2), pp. 701-28.
Aghion, Philippe; Blundell, Richard W.; Griffith, Rachel; Howitt, Peter and Prantl, Susanne. "The Effects of Entry on Incumbent Innovation and Productivity." Centre for Economic Policy Research, CEPR Discussion Papers: No. 5323, 2005b.

-Grossman, Sanford J. and Hart, Oliver D. "The Costs and Benefits of Ownership: A Theory of Vertical and Lateral Integration." Journal of Political Economy, 1986, 94(4), pp. 691719.

-Hart, Oliver and Moore, John. "Property Rights and the Nature of the Firm." Journal of Political Economy, 1990, 98(6), pp. 1119-58.

Whinston, Michael D. "Assessing the Property Rights and Transaction-Cost Theories of Firm Scope." American Economic Review, 2001 (Papers and Proceedings), 91(2), pp. 184-88.

Williamson, Oliver E. The economic institutions of capitalism. New York: Free Press, 1985.

Williamson, Oliver E. Markets and hierarchies: Analysis and antitrust implications. New York: Free Press, 1975. 


\section{This article has been cited by:}

1. Laura Alfaro, Paola Conconi, Harald Fadinger, Andrew F. Newman. 2016. Do Prices Determine Vertical Integration?. The Review of Economic Studies rdv059. [CrossRef]

2. Evangelia Chalioti. 2015. Incentive contracts under product market competition and R\&D spillovers. Economic Theory 58, 305-328. [CrossRef]

3. Hao-Chen Huang, Mei-Chi Lai, Wei-Wei Huang. 2015. Resource complementarity, transformative capacity, and inbound open innovation. Journal of Business \& Industrial Marketing 30:7, 842. [CrossRef]

4. Otello Ardovino, Luca Pennacchio, Giuseppe Piroli. 2014. Cooperazione in ricerca e sviluppo e attività innovativa delle imprese: un'analisi empirica della realtà italiana. STUDI ECONOMICI 68-98. [CrossRef]

5. P. Legros, A. F. Newman. 2014. Contracts, Ownership, and Industrial Organization: Past and Future. Journal of Law, Economics, and Organization 30, i82-i117. [CrossRef]

6. Hao-Chen Huang, Mei-Chi Lai, Meng-Chun Kao, Chien-Hui Sung. 2014. A team-learning framework for business model innovation in an emerging market. Journal of Management \& Organization 20, 100-120. [CrossRef]

7. P. Legros, A. F. Newman. 2013. A Price Theory of Vertical and Lateral Integration. The Quarterly Journal of Economics 128, 725-770. [CrossRef]

8. Shenglan Chen, Kun Wang, Xiaoxue Li. 2012. Product market competition, ultimate controlling structure and related party transactions. China Journal of Accounting Research 5, 293-306. [CrossRef]

9. Kai Xu, Kuo-Feng Huang, Shanxing Gao. 2012. The effect of institutional ties on knowledge acquisition in uncertain environments. Asia Pacific Journal of Management 29, 387-408. [CrossRef]

10. Kuo-Feng Huang, Chwo-Ming Joseph Yu. 2012. Cross-Regional Patenting. Management International Review . [CrossRef]

11. Vey Wang, Chung-Hui Lai. 2011. Franchise fee, competition and economic growth. Economic Modelling 28, 2090-2099. [CrossRef]

12. Kai Xu, Kuo-Feng Huang, Shanxing Gao. 2011. Who Can Cultivate University Ties More in China\&\#63; A Local Firm or a Foreign Firm\&\#63;. IEEE Transactions on Engineering Management 58, 250-261. [CrossRef]

13. Kuo-Feng Huang, Chwo-Ming Joseph Yu. 2010. The effect of competitive and non-competitive R\&D collaboration on firm innovation. The Journal of Technology Transfer . [CrossRef]

14. Susan V. ScottUnderstanding the Characteristics of Techno-Innovation in an Era of Self-Regulated Financial Services 166-188. [CrossRef]

15. Shanxing Gao, Kai Xu, Jianjun Yang. 2008. Managerial ties, absorptive capacity, and innovation. Asia Pacific Journal of Management 25, 395-412. [CrossRef]

16. Rachel Griffith. 2007. Technology, Productivity and Public Policy. Fiscal Studies 28:10.1111/ fisc.2007.28.issue-3, 273-291. [CrossRef] 